\title{
Youth Pioneering in Sustainable Development
}

\author{
Epin Saepudin \\ Institut Teknologi Bandung \\ Bandung, Indonesia \\ epin.saepudin@itb.ac.id
}

\author{
Karim Suryadi, Elly Malihah \\ Universitas Pendidikan Indonesia \\ Bandung, Indonesia \\ karimsuryadi@upi.edu, ellyms@upi.edu
}

\begin{abstract}
The existence of government's limitation in implementing the development programs makes the need for community involvement as beneficiaries and practitioners of the development in the culture of democracy. This study aimed to describe the contribution of youth in supporting the sustainable development. The study was conducted by using qualitative approach with case study method. The results showed that youth pioneering strength-based collaborative community became the major force in achieving the targets and the goals of sustainable development. Community became incubators in developing and internalizing the values of volunteerism, creativity, and innovation of youth in democratic governance management based on sustainable triangle, namely the balance of economic, social and environmental development.
\end{abstract}

Keywords-community; democratic governance; sustainable development; volunteerism; youth pioneering

\section{INTRODUCTION}

History records that the progress of countries in various parts of the world cannot be separated from the contribution of youth as a major milestone in the struggle of the nation. The reality also occurs in Indonesia, where the collective spirit of the youth who become members of youth organizations is a major force pushing Indonesia into an independent, sovereign and state equal with other nations around the world. The birth of modern organization Budi Utomo in 1908 showed the evidence that the national movement was started from the thoughts of Indonesian young intellectuals [1], [2], [3]. Youths at that time were a group of dreamers who wanted a "new life". The dream that finally gave birth to the awareness of the meaning, nature and identity of the youth as actors of changes which was in sociological point of view had shown a strong tendency to establish ties of solidarity [4]. Such youth pioneering spirits, ideally not only required before and at the time of independence, but are also required to fill out and to run the post-independence development with all the complexity of the problems.

This study is based on at least four ways. First, the government as the executor of development has its limitations, both in terms of human resources, budgeting, etc. Therefore government needs support from various parties. Second, in general the implementation of development in Indonesia has not optimally increased the involvement of the community to participate actively. Third, the existence of denial on public participation makes the growing public awareness to create pseudo democracy into essential democracy both procedurally and substantially. Fourth, the implementation of development in Bandung city seen from the sustainable triangle, has not reached equilibrium, where the environmental aspect is still far behind from economic and social aspects. Such reality shows lack of awareness of each elements of the community towards environmental sustainability in development [5].

Seen from sustainable triangle, the implementation of development has not reached equilibrium. The government showed good performance in the field of economic and social, but environmental protection is getting left far behind [6]. Seeing the results, the government together with the community should carry out and support all the implemented sustainable development programs fully. The development praxis should be based on the principle of sustainability which is conducted to meet the demands of today's life without forgetting the demands and the needs of future generations by integrating economic, social and environmental development in harmony and balance [7]. The logic is that the economic and social well-being cannot be improved by the actions that destroy the environment. These three dimensions are interrelated and become the driving force pillars for sustainable development [8].

A characteristic of these conferences is their focus on active engagement and student empowerment; delegates receive training in campus sustainability (e.g. how to conduct a campus sustainability audit or a greenhouse gas emissions (GHG) assessment) and environmental activism (e.g. non-violence workshop). Apart from the inspiration generated by a large coming together of "like minds", the SYC Sustainable Campuses conferences are appealing in that they demonstrate sustainability and social justice in action: every effort is made to minimize the ecological footprint of the meeting, for instance, by offsetting GHG and serving local, certified organic, and certified fair trade food; by reducing attendees' costs by billeting visiting students with local students; and by subsidizing, where possible, travel costs for long-distance delegates, with corporate and government donations being scrutinized through a very strict SYC sponsorship policy [9].

The causes of its not maximal of sustainable development praxis are caused by several things. First, the government's political commitment has not fully understood the pattern of sustainable development [10]. Second, some local leaders have not been able to implement sustainable development in accordance with National Medium Term Development Plan (NMTDP) which is seen from the many activities of environmental destruction, merely to boost their regional economic income [11]. Third, current Indonesia's economy still 
relies on the natural resources sector, where the exploitation of natural resources are too extractive, as though this sector is natural resources that will not be exhaust [12]. Fourth, the lack of public awareness on the maintenance and preservation of environment [13].

Seeing some of the above problems, youth pioneering becomes one of the important factors that must be built to support the implementation of sustainable development. Environmental conservation programs can run optimally if it is supported by bottom-up approach in the form of social movements [14]. Youths with all their potential and fresh blood coursing through their veins are the main force that make fiery and immediately want to realize their ideas in the context of real life.

\section{METHOD}

This research on building youth pioneering in supporting sustainable development used qualitative approach with case study method. Location of the study was spread in four points, including; Bandung Creative City Forum Office, Dago Corner Creative Village, Cicadas Acoustic Village, and Babakan Siliwangi Area with research subjects consisted of the officers, members and participant of Bandung Creative City Forum community. The techniques of collecting data were interviews, observation and documentation study. The data were analysed using Milles and Huberman model, including; data reduction, data display and verification [15]. To increase the degree of trust on the research data, triangulation based on the data collection techniques and triangulation based on data sources were used.

\section{RESULT AND DISCUSSION}

\section{A. Building Youth Pioneering through Community}

Bandung Creative City Forum (BCCF) as a gathering place for the youth of Bandung consists of various communities coming from different backgrounds, either business, social, environment, music, and other hobbies community. The differences in every communities of BCCF are rated as a force draining positive energy if it can be put together, can be empowered and can be driven along together. Variety of communities with the different flat form is then assembled with one vision that is to perform a variety of creative activities for the betterment of Bandung city. To create synergy, collaboration, and youth pioneering in supporting the development efforts, BCCF puts "rabuan" and design thinking as core activity and is the basis for community movement.

First, rabuan. This activity is a routine activity held by BCCF every Wednesday in order to capture and to share information on the development of creative activity undertaken by communities joined in BCCF. This program is a form of the existence of communication, coordination and transfer of information among communities. Discussions in rabuan activity produce some positive things, such as; the increasing of members' understanding and knowledge about the role and position of the community in encouraging the advancement of society, the growing of power and creative thinking in entrepreneurship, stimulating members to always do creative activities, and other positive values. Through this activity, there is a shift in the thinking from working into creating jobs, from freedom lovers into independence filler, from development connoisseurs into development practitioners, and so on. This activity is a positive trend which is currently developing in which people in various world enter a major transformation in the economy, namely creative economy [16].

Second, design thinking. This activity is an event that brings together the activists of different scientific backgrounds to resolve a same problem. The results of design thinking is expected to not only produce concept that will disappear after the implementation of the activities, but also the follow up actions of the ideas born in the discourse, namely how to speed up the development of the city by completing all the complexities involved. Design thinking is regarded as a scheme or a workable methodology in solving various problems through the use of thought and potential of youths which in praxis is divided into several steps, namely; formulation of the problem, problem identification, discussion and exchange of opinions on a variety of problem solving ideas, until finally find a conclusion. One of the topics raised in the design thinking is "urban mobility" which aims to form habits, attitudes and character, as well as preparedness to become citizens of the city. Design thinking focuses on the activity of perception, the possibility, and practices that ultimately resulted in an innovation for solving problems that becomes the focus of the study [17]. Through this design thinking, born a prototype of alternatives that can be used to solve the problems. This activity can encourage the emergence of an effective habits in a person that is the meeting point among knowledge, skills and desire [18].

Rabuan and design thinking activities are driven by an understanding that "Hidup adalah Udunan" (life is collaboration) which eventually lead to three major elements as BCCF missions, namely connection, collaboration, and commerce. This jargon becomes the substance of a value of solidarity in social movements built by the community to perform activities together. Thee principle which is in harmony with the ideology of Indonesia (the third and the fourth principle of Pancasila) becomes basic strength of the organization that has implications for the passage of nongovernmental concept ideally. Youth and adults are challenged to bring their own perspectives, experiences, and networks into the partnership. By doing so, they can potentially promote community change by stimulating critical discourse, skill development, participatory inquiry, and collective action [19], [20], [21].

\section{B. City Acupuncture as Sustainable Development Strategy}

Real action of Bandung Creative City Forum (BCCF) community in supporting sustainable development can be seen on the city acupuncture strategy applied to help the government in resolving the sustainable development program. The strategy derived from the alternative medicine concept is a method of searching for points of central issues. In the perspective of sustainable triangle [22], at least the central problem of Bandung city lies in three aspects, namely the economic community that has not been prosperous overall, social life that often creates turmoil, as well as the lack of attention to the 
aspects of the environment maintenance in implementing the development programs [23].

At least there are three programs as a form of social movement that is initiated by BCCF through acupuncture method. First, TUNZA International Children and Youth Conference on the Environment activity in collaboration with United Nations Environment Programmer (UNEP) and the Ministry of Environment (MOE) of Indonesia with the theme "Babakan Siliwangi World City Forest" which contains forest walk, forest art and dance, the inauguration of Babakan Siliwangi as the world's urban forest, review of Babakan Siliwangi bridge, and tree planting. This activity is in response to the lack of attention to environmental aspects (Babakan Siliwangi) in the implementation of the development dominated by economic development [23].

Second, creative village formation as an effort to solve the problems of poverty, social inequality, and the decrease of pride to the village occurred in Bandung city. Through these activities, it is expected that the villages become a model and a true example of a social movement to create economic and social independence of the people, as seen in Dago Corner Creative Village and Cicadas Acoustic Village. Dago Corner Creative Village with the characteristics of small street, dense, houses cheek by jowl, limited drains, and unemployment was later developed into a tourist village as a centre of culture and economic development. The alleys in Dago Corner Village are decorated with murals as public art [24]. Seedy alley wall that doubles as a wall painting eventually attracts tourists to come. The number of tourists coming to Dago Corner Creative Village, also implicates reducing the number of unemployment there. People who do not work can earn a fortune by selling trinkets typical of Bandung city, food, and others that contribute to increasing people's incomes. In addition, BCCF activists also provide training services to citizens, such as batik course, recycling waste, urban farming, and so forth so that adds the people's skills. Cicadas Acoustic Village known as densely populated, narrow alleys, income derived by some people by singing, as well as many social cohesion that sparked the presence of criminal actions encourage BCCF to form a creative community by gathering street singers for later facilitated to spawn numerous songs that are worth selling, and can be enjoyed by the public [25].

Third, initiating "Street Urban Farming" activities organized by $\mathrm{BCCF}$ in collaboration with Bandung Gardening community, Taman Sari residents, United Nations Environment Programmer (UNEP), and the Ministry of Environment invites people around Taman Sari to perform collective gardening and tree planting. Urban farming followed systematically by Bandung Gardening Community at various points in the city has an impact on education, economic, social, and ecology for the community. In addition, urban farming can also serves as a vehicle for internalizing the values of civility in the field of the environment through citizens' intellectual and skills development in environmental governance activities independently [25].

\section{Youth Pioneering in Sustainable Development}

Youth pioneering becomes one of the aspects that should be developed in supporting the success of sustainable development. That is because the youths have at least seven positive characteristics inherent in, among others; team spirit, creativity, innovative, opened, likes a challenge, strong-willed, and never-surrender. Besides that the purity of idealism, courage in absorbing the values and new ideas, the spirit of dedication and their desire to show the independent attitudes and personalities that make the role of the youth very strategic for being the development actors [26].

Youth pioneer label is closely related to the position of youth as agent of change that is capable of running the power and potential in themselves for the welfare of the nation and the state [27]. The importance of increasing the involvement of youth in the development process, because young people do not just become a connoisseur of independence, but rather participate actively in the independence activities [28]. State relies on great hopes on the shoulders of the youth to make a change, not only to enjoy independence but also as successor, the charger once the guard of independence. It is said as the guards of independence, because we realize it or not, we are now occupied. Not through confrontation and take up arms, but rather through cultural colonization, advances in science and technology and other things that lull young people with everything that is instant and pragmatic. Building youth pioneering and involvement in the development is a strategic move considering the youth is a segment that has great energy and high innovation power, which if excluded would likely have implications for the birth of the social problems that are not desirable.

The development of youth pioneering through the community in the study of civic education is known as the concept of site citizenship, that is a vehicle for selfactualization of citizens in public life [29]. The existence of BCCF community strongly supports the implementation of sustainable development programs launched by the Bandung City government which concentrates on nine issues of strategic development, among others; environment, infrastructure, the development of information and communication technology; community empowerment and family resilience; poverty, social problems and unemployment; education and culture; health; reformation of the bureaucracy and governance; and business, tourism and creative economy climate [30].

We live with growing awareness of the complexity of sustainability and the challenges presented by our present patterns of life. Although ecological and humanitarian problems persist, opportunities for creative response continually emerge in line with our increasing understanding of these dynamics. Since, the 2002 Johannesburg Summit, the special role of our education systems in facilitating, envisioning, and leading change towards sustainability has been the focus of renewed attention. Higher Education (HE) in particular prides itself on being at the vanguard of vision and wisdom, and its core values point to its potential leadership role across societies. This special issue has been compiled with this role in mind and presents a series of cases and perspectives from the Asia-Pacific region, to showcase new efforts to 
accelerate innovation for sustainability in HE. It is clear that to date, examples of sustainability initiatives from Australia and New Zealand have been most widely published, but developments in other parts of the region have received less consideration [31].

The mission of sustainable development that balances economic, social, and environment will shift development paradigm that still adhere The Stage of Economic Growth theory which has been used for 20 years as development framework and nearly tied in the pattern of dependence [32]. The mission of sustainable development in Bandung city is expressed in 10 dreams of the future of Bandung, among others; designing city park as comfortable as family room, reversing traffic for the convenience of the residents, providing modern public buildings, applying art on the element of the city, providing creative corner and development center buildings, motivating the walking activities for the warmth of social interaction, celebrating togetherness with the diversity of the festivals, returning Cikapundung river to its nature, reorganizing the city faces from chaotic billboards, facilitating environment with green policy [33].

Sustainability is not a contemporary phenomenon, but the solutions undertaken on the most successful Canadian Campuses have taken an innovative turn. Sustainable ways of life have been embedded within and across many cultures throughout history especially through North American Indigenous ways of knowing [34]. Youth pioneering in supporting sustainable development is a voluntary movement of citizens (civic voluntarism movement) because it shows a number of characteristics and pro social behavior, namely; sharing, cooperating, helping, donating, and honesty [35]. Voluntarism movement is characterized by the emergence of caring attitude and sense of willing to do something, finding out what is going on, as well as their desire to change the environment into the better one [36]. The movement emerges when someone looks at the environmental conditions that are not in accordance with the ideals or principles of fairness, namely the development process disregarding the aspects of sustainability.

In a world of increasing internationalization, individual nations are increasingly extending and inter-penetrating their environmental impacts and ecological footprints. Thus, the "new age" of sustainability demands a matching internationalization of environmental management and stewardship. Consequently, there is a need for people trained to work in an international setting, with a sound understanding of sustainability issues and the mechanisms for tackling them; or in a local setting with an international perspective [37]. The United Nations' Decade on Education for Sustainable Development or DESD (2005-2014) encompassed action themes, including overcoming poverty, achieving gender equality, health promotion, environmental protection, rural development, cultural diversity, peace and human security, and sustainable urbanization [38]. Education for Sustainable Development as "an approach to teaching and learning based on the ideals and principles that underlie sustainability" including with key issues [39].
Voluntarism as a manifestation of youth pioneering is the root of democracy because it focuses on the active participation of the citizens in encouraging the implementation of the development [40]. It is said so because conceptually, the principles and the objectives, the principles of sustainable development are very relevant to a number of principles in democracy, namely; equity and justice, integrative approach, long-term perspective, ecological sustainability, economic sustainability, social and cultural sustainability, political sustainability, as well as defence and security sustainability. The growing of public awareness on the concept and practice of democracy, the process of democratization in Indonesia shifts from pseudo democracy into essentials substantive democracy [41]. Relationships and social transactions among young people and adults in community settings have become a focus of research and practice [42], [43], [44]. Within the context of youth civic development, youth adult-partnership (Y-AP) has become a phenomenon of particular interest. Conceptualized as both a developmental process and as a community practice, Y-AP involves citizens across generations working together to address common concerns. Grounded in the frame of 'free spaces' [45].

\section{CONCLUSION}

Youth pioneering awakened through integration, collaboration and creative synergy among communities in Bandung city contributes in supporting the achievement of the concept and practice of sustainable development. The youth volunteerism to share with others makes the efforts to improve the quality of people's life in the social and economic aspects can systematically evolve in harmony with environmental preservation. The synergy between the government and the public that shows the nuances of mysticism as implied in ideology of Pancasila has contributed to the creation of substantive democracy that emphasizes on the active involvement of the community in charging and running the development.

\section{ACKNOWLEDGMENT}

Thanks to every member of Bandung Creative City Forum (BCCF) who are willing to take the researcher as a member to conduct this study. In addition, thanks to Residents of Dago Pojok Creative Village and Cicadas Acoustic Village for the hospitality and assistance during data collection process.

\section{REFERENCES}

[1] R.Z. Leirissa, Sejarah Pemikiran Tentang Sumpah Pemuda, Jakarta: Departemen Pendidikan dan Kebudayaan, 1989.

[2] J.D. Legge, Kaum Intelektual dan Perjuangan Kemerdekaan: Peranan Kelompok Syahrir, Jakarta: Pustaka Utama Grafiti, 1993.

[3] M.C. Ricklefs, Sejarah Indonesia Modern, Yogyakarta: Gadjah Mada University Press, 2005.

[4] Martha, G. Ahmaddani, W. Christianto, and A. Yozar, Pemuda Indonesia dalam dimensi sejarah perjuangan bangsa, Jakarta: Yayasan Sumpah Pemuda, 1984.

[5] S. Sudarmadi, S. Suzuki, T. Kawada, H. Netti, S. Soemantri, and A.T. Tugaswati, "A survey of perception, knowledge, awareness, and attitude 
in regard to environmental problems in a sample of two different social groups in Jakarta, Indonesia," Environment, development and sustainability, vol. 3, No. 2, pp. 169-183, 2001.

[6] I. Sari, and H. Prabatmodjo, "Evaluasi Keberlanjutan Kota Bandung," Jurnal Perencanaan Wilayah dan Kota B SAPPK V2N3, Sekolah Arsitektur, Perencanaan dan Pengembangan Kebijakan ITB, Bandung, 2012.

[7] International Institute for Sustainable Development, Sustainable Development: From Brundtland to Rio 2012 (Consideration by the High Level Panel on Global Sustainability), New York: United Nations Headquarters, 2010.

[8] R.R. Wrihatnolo, Manajemen Privatisasi BUMN, Jakarta: Elex Media Komputindo, 2008.

[9] A. Beringer, "Campus Sustainability Audit Research in Atlantic Canada: Pioneering The Campus Sustainability Assessment Framework," International Journal of Sustainability in Higher Education, vol. 7, No. 4, pp. $437-455,2006$.

[10] D. Sari, "Pengaruh Sistem Pengendalian Intern Pemerintah, Implementasi Standar Akuntansi Pemerintahan, Penyelesaian Temuan Audit terhadap Penerapan Prinsip-Prinsip Tata Kelola Pemerintahan yang Baik (Penelitian pada Pemerintah Daerah di Provinsi Jawa Barat dan Banten)," Indonesia Journal of Economic and Business, vol 16, pp. 116-124, 2013.

[11] A. Damayanti, Kebijakan Pembangunan Wilayah Berbasis Pengelolaan DAS Terpadu dan Berkelanjutan, Bogor: IPB, 2010.

[12] H. Kartodihardjo, and A.S. Suntana, Penataan dan Pengelolaan Sumber Daya Alam: Gagasan Prof. Emil Salim dan Implementasinya. Pembangunan berkelanjutan: peran dan kontribusi Emil Salim, Iwan et all ed, Jakarta: Kepustakaan Populer Gramedia, 2010.

[13] A.P. Hadi, Y. Agribisnis, and P.P.M. Agrikarya, "Tinjauan terhadap berbagai program pemberdayaan masyarakat di indonesia," Yayasan Agribisnis/Pusat Pengembangan Masyarakat Agrikarya (PPMA), 2009.

[14] C. Certoma, and B. Notteboom, "Informal Planning In A Transactive Governmentality: Re-reading Planning Practices Through Ghent's Community Gardens," Planning Theory, pp. 1-24, 2015.

[15] M.B. Miles, and A.M. Huberman, "Analisis Data Kualitatif, Buku Sumber Tentang Metode-Metode Baru, Jakarta: Universitas Indonesia Press, 2012.

[16] R. Florida, The Rise of the Creative Class: And How It's Transforming Work, Leisure, Community, and Everyday Life, New York: Basic Book, 2003.

[17] P. Suprobo, Kajian Design Thinking: Proses Metakognisi dalam Pelaksanaan Proyek Desain Produk (Studi Kasus Proyek Studio Desain Produk bertema Eksplorasi Bentuk), Prosiding Seminar Nasional Teknoin, 2012.

[18] S.R. Covey, Seven Habits of Highly Effective People: Powerful Lessons in Personal Change, New York: Simon and Schuster, 1989.

[19] Linds, Warren, G. Linda, and S. Ali, Emancipatory practices: Adult/youth engagement for social and environmental justice, Rotterdam, the Netherlands: Sense Publishers, 2010.

[20] I. Prilleltensky,. "Psychology and The Status Quo," American Psychologist, vol. 44, No.5,pp. 795-802, 1989.

[21] S. Zeldin, B.D. Christens, and J.L. Powers, "The psychology and practice of youth-adult partnership: Bridging generations for youth development and community change," American journal of community psychology, vol. 51, No. 3-4, pp. 385-397, 2013.

[22] United Nations, "Sustainable Develoment Knowledge Flatform" Retrived from http://sustainabledevelopment.un.org/index.php?menu, accesed May 2014.
[23] I.M. Ridwan, and D. Achmad, "Destination Branding Hutan Babakan Siliwangi," ITB Undergraduate Journal of Visual Art and Design, vol. 1, No. 1, 2012.

[24] M. Miles, Art, Space, and the City: Public Art and Urban Futures, New York: Routledge, 1997.

[25] W. H. Prasetiyo, D. Budimansyah, and N. Roslidah, "Urban Farming as a Civic Virtue Development in the Environmental Field," International Journal of Environmental and Science Education, vol. 11, No. 10, pp. 3139-3146, 2016.

[26] T. Abdullah, and M. Yasin, Pemuda dan Perubahan Sosial, Jakarta: LP3ES, 1974.

[27] I. Kusumah, Risalah Pergerakan Mahasiswa, Bandung: Alumni, 2007.

[28] A. Gonggong, "Peranan Pemuda dalam Sejarah Perjuangan Bangsa," Warta Sejarah vol.7, No. 11, 2008.

[29] U.S. Winataputra, and D. Budimansyah, Civic Education: Konteks, Landasan, Bahan Ajar dan Kultur Kelas, Bandung: School of Postgraduated, Universitas Pendidikan Indonesia, 2007.

[30] Bandung City Regulation No. 03 Year 2014 on the Medium Term Development Plan of Bandung City Year 2013 - 2018.

[31] A. Ryan, D. Tilbury, P. Blaze Corcoran, O. Abe, and K. Nomura, "Sustainability in higher education in the Asia-Pacific: developments, challenges, and prospects," International Journal of Sustainability in Higher Education, vol. 11, No. 2, pp. 106-119, 2010.

[32] Sasono and Arif, Indonesia: Dependency and Underdevelopment, Kuala Lumpur: Meta, 1980.

[33] R. Kamil, Mengubah Dunia Bareng-Bareng, Bandung: Mizan Kaifa, 2015.

[34] R.C. Mitchell, "Sustaining Change on A Canadian Campus: Preparing Brock University for A Sustainability Audit," International Journal of Sustainability in Higher Education, vol. 12, No. 1, pp. 7-21, 2011.

[35] Mussen, Essential of Child Development \& Personality, New York: Harper \& Row Publisher Inc, 1980.

[36] L. Hilman, Filantropi Islam dan Ideologi Kesejahteraan Kaum Modernis, Jakarta: PT Gramedia Pustaka Utama, 2010.

[37] J. Fien, and T. Trainer, "Education for Sustainability Environmental Education: A Pathway to Sustainability," Retrieved from https://doi.org/10.1108/14676370710717553, accesed October 2016.

[38] UNESCO, "United Nations Decade of Education for Sustainable Development (2005-2014. Framework for the International Implementation Scheme)," Retrieved from http://unesdoc.unesco.org/ images/0013/001311/131163e.pdf , accessed December 2016.

[39] H. Kopnina, and F. Meijers, "Education for sustainable development (ESD)," International Journal of Sustainability in Higher Education, vol. 15, No. 2,pp. 188-207, 2014.

[40] Djajadinigrat, Penetapan Baku Mutu Lingkungan Air Limbah Rumah Tangga, Bandung: Pusat Penelitian Pengembangan Pemukiman Departemen Pekerjaan Umum, 1992.

[41] S. Haris, Masalah-Masalah Demokrasi dan Kebangsaan Era Reformasi, Yayasan Pustaka Obor Indonesia, 2014.

[42] S.D. Evans, and I. Prilleltensky, "Youth and Democracy: Participation for Personal, Relational, and Collective Well-being," Journal of Community Psychology, vol. 35, No. 6, pp. 681-692, 2007.

[43] E. Seidman, "An Emerging Action Science of Social Settings," American journal of community psychology, 2011.

[44] N.T. Wong, M.A. Zimmerman, and E.A. Parker, "A typology of youth participation and empowerment for child and adolescent health promotion," American Journal of Community Psychology, vol. 46, No. 1-2, pp. 100-114, 2010.

[45] S.M. Evans, and H.C. Boyte, Free Spaces: The Source of Democratic Change in America, Chicago: University of Chicago Press, 1992. 